DOI

\title{
МОРФОМЕТРИЧНА ОЦІНКА СТРУКТУРНОЇ ВІКОВОЇ ПЕРЕБУДОВИ ПІДШЛУНКОВОЇ ЗАЛОЗИ ПРИ АРТЕРІАЛЬНІЙ ГІПЕРТЕНЗІЇ В МАЛОМУ КОЛІ КРОВООБІГУ
}

\author{
๑А. П. Мокра, А. Г. Шульгай \\ ДВНЗ «Тернопільський державний медичний університет імені І. Я. Горбачевського МОз України»
}

\begin{abstract}
РЕЗЮМЕ. Морфологічними методами вивчені особливості ремоделювання ацинарних відділів підшлункової залози молодих та старих щурів при пострезекційній артеріальній легеневій гіпертензії. Встановлено, що в умовах змодельованої патології зменшуються діаметр та площа ацинусів, настають дистрофічні зміни у екзокринних панкреатоцитах, відбуваються диспропорційні зміни об'ємних співвідношень ядра та цитоплазми, зростання показника ядерно-цитоплазматичних відношень, збільшується відносний об'єм стромального компонента. Структурні зміни підшлункової залози переважали у старих тварин.

КЛЮчОВІ СЛОВА: підшлункова залоза, екзокринні панкреатоцити, пострезекційна легенева артеріальна гіпертензія.
\end{abstract}

Вступ. В останні роки як в Україні, так і у більшості країн світу спостерігається зростання демографічного навантаження внаслідок кількісного збільшення осіб, старших працездатного віку. у зв'язку з цим відбувається зміна в структурі поширеності хвороб з переважанням хвороб системи кровообігу $[1,2]$. Враховуючи даний фактичний матеріал повинні змінюватися також пріоритети наукових досліджень, які мають бути направлені на вирішення проблем теоретичної та клінічної геронтології з питань лікування та профілактики хвороб системи кровообігу [3]. До причин, що сприяють порушенню кровообігу, належить серцева недостатність, яка розвивається на тлі гіпертензії у малому колі кровообігу. Щорічна статистика підтверджує динамічне зростання хронічних обструктивних захворювань легень, збільшення їхньої питомої частки серед причин інвалідності та смертності різних вікових груп населення [4].

Підвищення тиску у системі легеневої артерії впливає не тільки на морфофункціональний стан органів малого кола кровообігу, але й сприяє розвитку недостатності кровообігу у великому колі. Внаслідок цього зменшується насиченість крові киснем, порушується органний кровообіг, відбува$\epsilon$ ться структурна перебудова у органах та тканинах $[5,6]$. При цьому у різних вікових групах населення спостерігаються різні адаптаційні реакції. Особливо чутливими до порушень кровообігу $є$ залози.

Підшлункова залоза як орган із поєднаною зовнішньо- та внутрішньосекреторною діяльністю та складною системою забезпечення органного кровообігу однією з перших проявляє адаптивні, пристосувальні та реактивні процеси ремоделювання [7-11]. У зв'язку з цим особливо актуальними $\epsilon$ вивчення вікових змін підшлункової залози та встановлення взаємозв'язків морфологічного стану її ацинарних відділів з екзокринною дисфункцією.
Метою дослідження було вивчення особливостей структурної перебудови ацинарних відділів підшлункової залози при пострезекційній легеневій артеріальній гіпертензії.

Матеріал і методи дослідження. Експериментальні дослідження проведені на 48 білих щурах-самцях, які були поділені на 4 експериментальні групи. До 1 групи увійшли 12 інтактних молодих щурів, віком 8 місяців, 2 групу склали 12 молодих щурів, яким було змодельовано гіпертензію у малому колі кровообігу, до 3 групи увійшли 12 старих щурів віком 24 місяці, до 4 групи - 12 старих щурів, яким було змодельовано гіпертензію у малому колі кровообігу. Гіпертензію у малому колі кровообігу у щурів моделювали шляхом виконання правобічної пульмонектомії, що призводило до легеневої гіпертензії, гіперфункції та гіпертрофії правого шлуночка (легеневе серце) [6]. Операції на тваринах виконували в умовах тіопенталового наркозу, з дотриманням правил асептики та антисептики. Тварин виводили з експерименту через 3 місяці від початку досліду шляхом кровопускання в умовах тіопенталового наркозу. Всі маніпуляції з дослідними щурами проводили із дотриманням правил, передбачених Європейською комісією з нагляду за проведенням лабораторних та інших дослідів 3 участю експериментальних тварин різних видів.

Дляпроведенняморфологічнихтаморфометричних досліджень вирізали шматочки підшлункової залози, які фіксували в 10 \% нейтральному розчині формаліну і після проведення через етилові спирти зростаючих концентрацій поміщали в парафін. Гістологічні зрізи товщиною 5-6 мкм фарбували гематоксиліном і еозином за ван Гізон та за Вейгертом.

Окремо забирали підшлункову залозу для виготовлення напівтонких зрізів, які забарвлювали толуїдиновим синім. 
Огляди літератури, оригінальні дослідження, погляд на проблему

Гістологічні мікропрепарати та напівтонкі зрізи досліджували світлооптично та морфометрично. Морфометрично визначали діаметр ядер екзокринних панкреатоцитів, діаметр ацинусів, кількість екзокринних панкреатоцитів на зрізі ацинуса. Вираховували площу ядер екзокринних панкреатоцитів, площу перерізу цитоплазми екзокринних панкреатоцитів, ядерно-цитоплазматичні відношення, площу перерізу ацинусів [6]. Окремо також визначали питому вагу паренхіми та питому вагу строми. Всі морфометричні вимірювання проводили за допомогою програми «Відео-Test-5,0».

Статистичну обробку даних, отриманих під час морфометричних вимірювань та обрахунків цифровихвеличин, проводили за допомогою програмного комплексу STATISTICA (Statsoft). Достовірність різниці між порівнюваними морфометричними показниками визначали за U-крuтерієм Манна-Уїтні. Статистично значимими відмінності вважали при $\mathrm{p}<0,05$.

Результати й обговорення. Одержані результати гістологічного аналізу та проведених морфометричних досліджень показали, що при формуванні гіпертензії у малому колі кровообігу настають структурні зміни у екзокринних відділах підшлункової залози, причому адаптаційні процеси ремоделювання залежать від віку тварин.

Гістологічними дослідженнями підшлункової залози статевозрілих щурів через 3 місяці після моделювання гіпертензії у малому колі кровообігу встановлено, що міжацинарна та міжчасточкова сполучна тканина знаходилася у набряклому стані, була розширеною з локальними розволокненнями. Явища набряку визначалися також у навколосудинних просторах, перипротоковій клітковині та супроводжувалися вираженою лімфоцитарною і гістіоцитарною інфільтрацією (рис. 1).

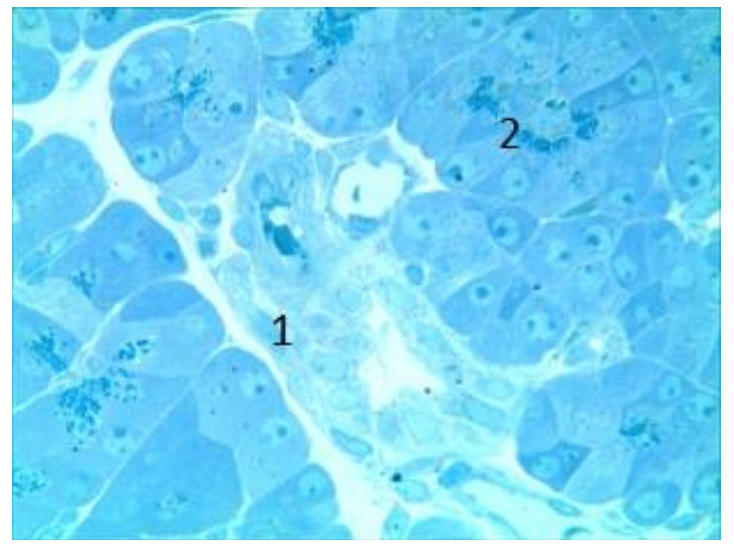

Рис. 1. Напівтонкий зріз підшлункової залози молодого щура через 3 місяці після моделювання легеневої гіпертензії: 1 - набряк та інфільтрація міжчасточкової сполучної тканини; 2 - зміна форми екзокринних панкреатоцитів. Забарвлення толуїдиновим синім. 36.: х 400.
Зустрічалися поодинокі макрофаги та плазматичні клітини. Характерною ознакою було збільшення питомої ваги стромального компонента у даної групи тварин від $(17,28 \pm 0,34) \%$ у інтактних щурів до $(23,04 \pm 0,37) \%$. Динаміка збільшення сполучної тканини при порівнянні дослідної та контрольної груп становила $32,56 \%$. Кровоносні судини були повнокровними, а вени - зі збільшеними просвітами, що свідчило про зростання опірності серед артеріального компонента та артеріол, а також порушення органного кровообігу.

Ацинуси змінювали свою форму з округлої на дещо видовжену. Діаметр ацинусів зменшувався на 16,32 \% з високим рівнем значущої різниці (табл. 1). При цьому площа ацинусів зменшувалася на $32,64 \%(p<0,001)$. Самі клітини ацинусів характеризувалися дистрофічними змінами. Кількість клітин, які формують ацинуси, зменшилася від $(7,96 \pm 0,42)$ до $(7,21 \pm 0,24)$, тобто на $10,40 \%$, що має значний вплив на кількісні величини секреторної діяльності, направленої на забезпечення функціональної активності.

Екзокринні панкреатоцити дистрофічно змінювалися. Серед екзокринних панкреатоцитів, які мали ознаки вогнищевої вакуольної дистрофії, часто виявлялися апоптично змінені клітини, які мали полігональну форму зі зморщеним, підвищеної базофілії ядром, конденсацією цитоплазми, конденсацією та маргінальним розташуванням хроматину. Міжклітинні щілини розширювалися. У багатьох ацинусах нерівномірні форми міжклітинних розширень сягали просвітів кінцевих відділів. Морфометричними дослідженнями екзокринних панкреатоцитів встановлено, що діаметр їх ядра у статевозрілих тварин, яким моделювали гіпертензію у малому колі кровообігу, зменшувався незначно і достовірно не відрізнявся від контрольних величин, проте при порівнянні площ ядер встановлено різницю з високим рівнем значущості $(p<0,001)$. При цьому площа ядра у тварин другої експериментальної групи була меншою від контролю на 3,48 \%. Морфометричні параметри цитоплазми характеризувалися односпрямованими з ядром змінами. Площа цитоплазми зменшувалася на $6,06 \%(p<0,001)$. Такі структурні зміни екзокринних панкреатоцитів підшлункової залози свідчать про те, що порушення системного кровообігу, які розвиваються при гіпертензії у малому колі кровообігу, призводять до зменшення функціональної активності клітин. Підтвердженням цьому було зростання параметрів показників ядерно-цитоплазматичних відношень. Отже, гіпертензія у малому колі кровообігу призводить до розвитку у підшлунковій залозі атрофічних та склеротичних змін, які належать до характерних ознак хронічного панкреатиту. 
Огляди літератури, оригінальні дослідження, погляд на проблему

Морфофункціональний стан зовнішньосекреторних відділів підшлункової залози у старих дослідних тварин, які входили до 3 експериментальної групи, за багатьма досліджуваними параметрами мав значущу достовірну різницю при

порівнянні з контрольними даними молодих статевозрілих щурів (табл. 1). Отримані вихідні дані гістологічного дослідження та морфометричного аналізу зазнавали суттєвих змін на тлі артеріальної гіпертензії у малому колі кровообігу.

Таблиця 1. Морфометрична характеристика ацинусів підшлункової залози білих щурів різних вікових груп

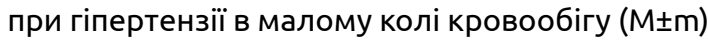

\begin{tabular}{|c|c|c|c|c|c|c|c|}
\hline \multirow[b]{2}{*}{$\begin{array}{c}\text { Група } \\
\text { спостереження }\end{array}$} & \multicolumn{7}{|c|}{ Досліджуваний параметр } \\
\hline & $\begin{array}{c}\text { площа ядер } \\
\text { екзокринних } \\
\text { панкреато- } \\
\text { цитів, мкм² }\end{array}$ & $\begin{array}{c}\text { діаметр } \\
\text { ядер екзо- } \\
\text { кринних } \\
\text { панкреато- } \\
\text { цитів, мкм }\end{array}$ & $\begin{array}{c}\text { площа } \\
\text { перерізу } \\
\text { цитоплазми } \\
\text { екзокринних } \\
\text { панкреато- } \\
\text { цитів, мкм² }\end{array}$ & $\begin{array}{c}\text { ЯЦВ екзо- } \\
\text { кринних } \\
\text { панкреато- } \\
\text { цитів, \% }\end{array}$ & $\begin{array}{c}\text { площа } \\
\text { перерізу } \\
\text { ацинусів, } \\
\text { мкM² }^{2}\end{array}$ & $\begin{array}{l}\text { діаметр } \\
\text { ацинусів, } \\
\text { мкм }\end{array}$ & \begin{tabular}{|c} 
кількість \\
екзокрин- \\
них панкре- \\
атоцитів \\
на зрізі \\
ацинуса
\end{tabular} \\
\hline $\begin{array}{l}1 \text { група (молоді } \\
\text { щури, інтактні) } \\
n=12\end{array}$ & $14,05 \pm 0,03$ & $4,23 \pm 0,03$ & $50,18 \pm 0,32$ & $0,28 \pm 0,02$ & $907,58 \pm 3,61$ & $34,21 \pm 0,18$ & $7,96 \pm 0,42$ \\
\hline $\begin{array}{l}2 \text { група (молоді } \\
\text { щури, гіпертензія } \\
\text { в малому колі } \\
\text { кровообігу) n=12 }\end{array}$ & $\begin{array}{c}13,58 \pm \\
0,02^{2 * * *}\end{array}$ & $4,16 \pm 0,01$ & $\begin{array}{c}47,31 \pm \\
0,19^{2 * * *}\end{array}$ & $0,29 \pm 0,01$ & $\begin{array}{l}683,58 \pm \\
4,72^{2 * * *}\end{array}$ & $\begin{array}{c}29,41 \pm \\
0,52^{2 * * *}\end{array}$ & $7,21 \pm 0,24$ \\
\hline $\begin{array}{l}3 \text { група (старі } \\
\text { щури, інтактні) } \\
\text { n=12 }\end{array}$ & $\begin{array}{c}13,32 \pm \\
0,04^{1 * * *}\end{array}$ & $4,12 \pm 0,02^{1 *}$ & $\begin{array}{c}53,83 \pm \\
0,46^{1 * * *}\end{array}$ & $0,25 \pm 0,01$ & $\begin{array}{l}807,86 \pm \\
4,281 * * *\end{array}$ & $\begin{array}{c}32,08 \pm \\
0,23^{1 * * *}\end{array}$ & $7,58 \pm 0,29$ \\
\hline $\begin{array}{l}4 \text { група (старі } \\
\text { щури, гіпертензія } \\
\text { в малому колі } \\
\text { кровообігу) n=12 }\end{array}$ & $\begin{array}{c}12,87 \pm \\
0,03^{3 * * *}\end{array}$ & $\begin{array}{c}4,02 \pm \\
0,01^{3 * *}\end{array}$ & $\begin{array}{c}42,01 \pm \\
0,38^{3 * * *}\end{array}$ & $\begin{array}{l}0,31 \pm \\
0,02^{3 *}\end{array}$ & $\begin{array}{l}527,83 \pm \\
6,94^{3 * * *}\end{array}$ & $\begin{array}{c}25,49 \pm \\
0,61^{3 * * *}\end{array}$ & $6,81 \pm 0,16^{3 *}$ \\
\hline
\end{tabular}

Примітка. Статистично достовірна різниця величин між групами спостережень: $1 *-p<0,05 ; i^{1 * *}-p<0,01 ; i^{1 * * *}-p<0,001$ - між параметрами 1 i 3 груп експерименту;

$2 *-p<0,05 ;{ }^{2 * *}-p<0,01 ;{ }^{2 * * *}-p<0,001-$ між параметрами 1 i 2 груп експерименту;

$3 *-p<0,05 ;^{3 * *}-p<0,01 ;{ }^{3 * * *}-p<0,001-$ між параметрами 3 i 4 груп експерименту.

У старих експериментальних тварин четвертої дослідної групи значно більш вираженими були дистрофічнізміни екзокриноцитів, які супроводжувалися загальним зменшенням площі ацинарних відділів. При цьому формувалися широкі фіброзні поля, які роз'єднували часточки, огортали протоки та кровоносні судини (рис. 2). Питома вага стро-

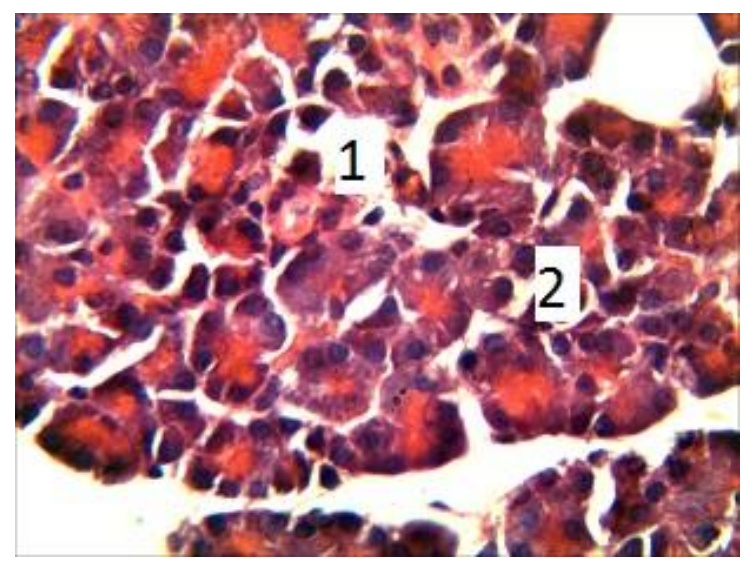

Рис. 2. Гістологічний зріз підшлункової залози старого щура через 3 місяці після моделювання легеневої гіпертензії: 1 - набряк та розширення міжацинарнихпроміжків; 2-дискомплексація ацинусів. Забарвлення гематоксиліном та еозином. 36.: х 400. мального компонента становила $(28,52 \pm 0,41) \%$ i на 35,21 \% переважала аналогічні параметри тварин третьої дослідної групи та на 65,03 \% - молодих статевозрілих щурів. Між даними величинами встановлена достовірна різниця $(p<0,001)$.

Більшість ацинусів були зміненими за формою, зменшеними в розмірах. Міжацинарні проміжки виповнювалися колагеновими волокнами. Діаметр ацинусів становив $(25,49 \pm 0,61)$ мкм і був меншим на 25,84 \% від діаметра ацинусів у інтактних старих щурів та на 34,21\% - від молодих статевозрілих щурів першої дослідної групи. При зіставленні ступеня зміни перерізу ацинусів при гіпертензії у малому колі кровообігу у молодих та старих щурів виявили, що даний параметр у старих щурів був на 15,37 \% меншим, що засвідчувало глибші структурні зміни ацинарних відділів у старих тварин. Площа ацинуса у тварин четвертої експериментальної групи була на 53,13\% меншою від аналогічних параметрів третьої експериментальної групи та на 29,60 \% - другої експериментальної групи ( $<<0,001)$. Кількість екзокринних панкреатоцитів, які утворюють ацинус, 3 достовірним рівнем значущості також була меншою 3 і 2 дослідних груп $(p<0,05)$. 
Огляди літератури, оригінальні дослідження, погляд на проблему

Серед популяції екзокринних панкреатоцитів спостерігалося зменшення діаметра ядра на 2,49\%. Ядра часто були змінені за формою та розташуванням, мали різний вміст хроматину. Діаметр ядер становив $(4,02 \pm 0,01)$ мкм, при $(4,12 \pm 0,02)$ мкм у інтактних старих щурів та $(4,16 \pm 0,01)$ мкм у тварин другої дослідної групи. Процеси зменшення площі ядра на 3,5 \% вказували на зменшення функціональної активності даного типу клітин. Площа цитоплазми зменшувалася на 28,13\%, при збільшенні показника ядерно-цитоплазматичних відношень на 24,01 \%. Причому даний параметр у старих щурів, яким виконували правосторонню пульмонектомію, був на 6,90 \% більшим, ніж у молодих статевозрілих щурів.

Таким чином, при порушенні органного кровообігу підшлункової залози внаслідок гіпертензії у малому колі кровообігу у старих тварин розвиваються явища хронічного панкреатиту з вираженими фіброзними та атрофічними змінами.

\section{ЛІТЕРАТУРА}

1. Дегтярева И. В. Структурные изменения в поджелудочной железе при ишемической болезни сердца / И. В. Дегтярева // Врачебное дело. - 2007. № 9. - С. 34-37.

2. Koopmann M. C. Total parenteral nutrition attenuates cerulein-induced pancreatitis in rats / M. C. Koopmann, M. D. Baumler, C. J. Boehler // Pancreas. - 2010. Vol. 39, № 3. - P. 377-384.

3. Мокра А. П. Вікові особливості морфометричних змін екзокринного апарату підшлункової залози / А. П. Мокра, А. Г. Шульгай, О. І. Пелешок // Вісник наукових досліджень. - 2015. - № 3. - С. 85-89.

4. Саркисов Д. С. Структурные основы адаптации и компенсации нарушенных функций / Д. С. Саркисов. М. : Медицина, 1987. - 448 с.

5. Tajho Kawbe. The genetics of essential metal homeostasis during development / Tajho Kawbe, Benjamin P. Weaver, Glen K. Andrews // Genesis. - 2008. - Vol. 46 (4). P. 214-228.

6. Автандилов Г. Г. Основы количественной патологической анатомии / Г. Г. Автандилов. - М. : Медицина, 2002. -240 c.
Висновки. 1. Тривала гіпертензія у малому колі кровообігу призводить до розвитку у підшлунковій залозі структурних змін, які полягають у збільшенні стромального та зменшенні паренхіматозного компонентів. Більше виражені фіброзні та атрофічні зміни характерні для старих тварин.

2. Атрофічні зміни підшлункової залози характеризуються зменшенням перерізу та площі ацинусів, зменшенням площі цитоплазми та ядер екзокринних панкреатоцитів, збільшенням ядерно-цитоплазматичних відношень, дистрофічними змінами екзокринних панкреатоцитів.

Перспективи подальших досліджень. Детальне вивчення процесів ремоделювання підшлункової залози при порушеннях кровообігу дозволить провести подальші дослідження, направлені на розробку адекватних методів запобігання розвитку структурних змін зовнішньосекреторних складових щодо збереження їі функціональної спроможності.

7. Богомолова И. Н. Гистоморфометрические показатели поджелудочной железы при отравлении алкоголем и наркотиками / И. Н. Богомолова // Судебно-медицинская экспертиза. -2003. - Т. 46, № 2.С. 16-20.

8. Можейко Л. А. Сравнительное изучение развития экзокринной и эндокринной части поджелудочной железы в постнатальный период / Л. А. Можейко, Я. Р. Мацюк, Е. Ч. Михальчук // Морфология. - 2006. T. 129, № 4. - С. 86.

9. Пащенко П. С. Изменения структуры поджелудочной железы после воздействия на организм гравитационных перегрузок /П. С. Пащенко // Морфология. 2006. - T. 129, № 1. - С. 62-67.

10. Романов В.И. Морфология панкреатических экзокриноцитов белых крыс при остром перегревании / В. И. Романов // Морфология. - 2006. - Т. 129, № 4. C. 106-107.

11. Charles Murtaugh L. Pancreas and beta-cell development: from the actual to the possible / L. Charles Murtaugh // Developmen. - 2007. - Vol. 134. - P. 427-438.

\section{MORPHOMETRIC VALUATION OF PANCREAS AGE-OLD STRUCTURE RECONSTRUCTION IN ARTERIAL HYPERTENSION IN THE PULMONARY CIRCULATION}

\section{@A. P. Mokra, A. H. Shulhai \\ SHEI «Ternopil State Medical University by I. Ya. Horbachevsky of MPH of Ukraine»}

SUMMARY. Using the morphological methods there were studied the remodeling pancreatic acinar parts in young and old rats with postresection pulmonary arterial hypertension. It was established that in a simulated pathology reduced diameter and area acini, began degenerative changes in exocrine pancreatic cells, take place disproportionate volume ratio of nucleus and cytoplasm, increasing of nuclear-cytoplasmic ratios, increased the relative amount of stromal component. Structural changes in the pancreas prevailed in old animals.

KEY WORDS: pancreas, exocrine pancreatic cells, postresection pulmonary arterial hypertension. 